\title{
Pogácsás Mihály: Hullámvölgyek, sodródás és lakhatás egy nő életében
}

\author{
Esettanulmány
}

\section{Bevezetés}

A Periféria Egyesület Utcai Szociális Munka Szolgálatnál dolgozom, mint szociális munkás. Az utcai szociális munka keretében célunk szolgáltatást nyújtani azoknak a hajléktalanoknak és hajléktalansággal veszélyeztetetteknek, akik életvitelszerüen utcán tartózkodnak, az intézményes ellátással szemben bizalmatlanok, és szolgáltatásait nem veszik igénybe. A Periféria Egyesület valósította meg a Hajléktalanokért Közalapítvány által finanszírozott „, 4 fö közterületen élö, vagy szívességi lakáshasználó személy önálló lakhatásának támogatása 12 hónapon keresztül" című programot, 2019. július 01. és 2020. június 30. között. Esettanulmányom egy 45 éves nőről szól, aki részt vett a programban.

\section{Kapcsolatba kerülés a klienssel}

Esettanulmányom alanya M. (ezentúl így fogom hívni). Ügyfelemet két éve ismerem. M. egy középmagas, átlagos termetü, rendezett külsejü nő. M. 1975-ben született V-ben, egy lánytestvére van. Az általános iskolát ott végezte. Időközben szüleivel és testvérével Nyíregyházára költöztek, mert M. édesapja munkát kapott a városban. M. a szakmunkásképzőt itt kezdte el, cipőfelsőrész-készítőnek tanult, amit nem fejezett be. M. középiskolás évei alatt „rossz társaságba” keveredett. Ez az életmód megrontotta szüleivel a kapcsolatot. M. a konfliktusok miatt inkább elköltözött otthonról és ismerősöknél húzta meg magát, szívességi befogadottként élte mindennapjait. M. élete hullámvölgyek sorozata volt. Néha-néha visszatért a szülői házba, előfordult, hogy albérletben lakott, de mivel nem volt rendszeres jövedelme, az albérlet nem tartott sokáig. Jellemzően szívességi befogadottként élt ismerőseinél.

2018 elején találkoztam elöször M.-mel. Az Egyesület irodáját látogatta meg. Személyes iratainak pótlásában kért segítséget, mivel elvesztette minden hivatalos papírját. M. együttműködő volt az ügyintézésben. Az ügymenet elörehaladtával egyre több információt osztott meg velem a segítő beszélgetésekben. Elmondta, hogy édesapja meghalt, édesanyjával némileg javult a kapcsolata, jelenleg nála lakik, de szeretne külön költözni egy albérletbe. Testvérével, és annak kisfiával jó a kapcsolata, sokat találkoznak. M. korábbi lázadó életének egy súlyos betegség kialakulása vetett véget. Pár évvel ezelőtt rosszindulatú melldaganatot állapítottak meg nála. Szerencsére időben orvoshoz került, a gyógyulási esélyei nagyon jók. Kemoterápiás kezelést kapott, jelenleg tünetmentes.

M párkapcsolatai nem voltak tartósak, erről azonban a mai napig nem szívesen beszél. M-nek betegségéből kifolyólag aktív korúak szociális ellátását, és egészségkárosodási támogatást állapítottak meg. Ezt azonban meg kellett szüntetni, ugyanis 2017 májusától intézményi és takarítói munkakörben helyezkedett el egy takarítócégnél. 


\section{Szociális anamnézis}

2018. július 01-én indult el az egyesület lakhatási pályázata. Az előkészítés szakaszában a program indulásáról tájékoztatást adtunk a program célcsoportjába tartozóknak. M.-mel korábban alkalomszerűen, a hivatalos ügyintézések miatt találkoztam az irodában, és ekkor kerültem vele rendszeres segítő kapcsolatba. Egy alkalommal meghallgatásra hívtuk be öt, ahol megkérdeztük a lakhatással kapcsolatos terveiről, jövőbeni elképzeléseiről. A program kezdete előtti hetekben került sor az ügyfelek kiválasztására, ahová végül M.-et is beválasztottuk. Következő nagy feladat volt az albérlet keresése. Felajánlottam albérlet-keresési szolgáltatásunkat neki. Több albérleti lehetőséget felhívtunk. Végül, egy jó ismerősének a közvetítésével sikerült egy számára megfelelő albérletet találni. A hónap első napján megkötöttük az albérleti szerződést, és ő elfoglalta a bérleményt.

Az albérlet a vasútállomáshoz közel, egy tégla építésű 4 emeletes társasház első emeletén található. Az ingatlan 35 négyzetméteres, egy szobából álló, jó állapotú lakás. Én is megtekintettem az ingatlant, és mindent rendben találtam. A beköltözést követően a fö cél a lakhatás hosszú távú megtartása volt. M. anyagi helyzetének megerősítését tűztük ki célul. Az ügyfél rendszeres jövedelemmel rendelkezett. Egy takarítócégnél dolgozott, mint takarítónő fóállásban. Viszonylag alacsony fenntartású bérleményről volt szó, ezért nem tünt problémának a bérleti díj és a fenntartási költségek fizetése. A program elején előfordult, hogy M. késve fizette be a rezsiszámlákat, egy-egy alkalommal megcsúszott a fizetéssel. Kértem, hogy tételesen nézzük át együtt a bevételi és a kiadási oldalt. Eleinte nehezen értette meg, hogy miért kell tételesen levezetni, M. nem látta reálisan a havonta felmerülő kiadásait, valamint nem kalkulált bizonyos kiadásokkal, alábecsülte azokat, de aztán hamar megértette, hogy így sokkal átláthatóbb a dolog. Szerencsére egészségi állapota továbbra is jó, jelenleg is tünetmentes. Kontrollra rendszeresen járnia kell, azokat komolyan veszi. Tavasszal a főbérlő úgy döntött, hogy megemeli az albérleti összeget, 30.000 Ft-ról 50.000 Ft/hóra. Így félő, hogy hosszú távon akár komoly anyagi terhet jelenthet a plusz bérleti díj kifizetése.

\section{A problémák}

A problémákat, több szempont alapján közelítettem meg: kapcsolatrendszer hiánya, egészségi, és lakhatási problémák.

\section{Kapcsolatrendszer hiánya}

M. a családi és egyéb rokoni kapcsolatait minimálisra csökkentette. Életének korai szakaszában kifejezetten rossz volt a kapcsolata szüleivel, bizalmukat elvesztette, elköltözött a szülői házból. Később javult a helyzet, újból közelebb kerültek egymáshoz. Testvérével javult a kapcsolata, rendszeresen tartják a kapcsolatot. Csatlakozott egy egyházi közösséghez, velük viszonylag folyamatos a kapcsolattartás. Külső környezetével a kapcsolatai inkább beszükültnek nevezhetők. 


\section{Egészségi állapot}

Az időközben kialakult daganatos betegség nem csak fizikailag, hanem lelkileg is megviselte. Az egykor széles baráti körrel rendelkező, társasági életet élö nő mentális állapotában ez a betegség nagyon sokat rontott. Rendszeresen kontrollra, felülvizsgálatokra kell járnia. Jelenleg tünetmentes.

\section{Lakhatási problémák}

M. jelenleg albérletben él. A közelmúltban bérleti díj emelkedés történt. Ez veszélyeztetheti a lakhatását. Emiatt (is) fontos a folyamatos, rendszeres munkaviszony, illetve a tartalékképzés elősegítése szociális munkás segítséggel.

\section{A problémák kialakulásának okai}

M. családi kapcsolatai megromlásáért (annak idején szüleivel) a fiatalkori lázadó magatartását tekinti kiváltó oknak. Később betegsége miatt befordult, s bizalmatlan lett a körülötte élő személyekkel. A társadalom által elvárt viselkedésnormáktól kis mértékben ugyan, de elfordult. Belépve az egyházközösségbe valamelyest javított az életszemléletén.

\section{Megfogalmazott célok}

\section{Rövid távú célok:}

- $\quad$ Rendszeres orvosi vizsgálatokon való részvétel, rendszeres kontroll.

- $\quad$ A munkaviszony megtartása

- $\quad$ Problémaspecifikus segítségnyújtás

- $\quad$ Programban való részvétel

\section{Középtávú célok:}

- $\quad$ Rendszeres orvosi vizsgálatokon való megjelenés

- $\quad$ Meglévő munkaviszony megtartása

- $\quad$ Kapcsolatrendszerének bővítése

- $\quad$ Albérlet hosszabb távú fenntartása

- $\quad$ Saját lábán megélni

- $\quad$ Programban való részvétel

\section{Hosszú távú célok:}

- $\quad$ Rendszeres kontroll, folyamatos orvosi vizsgálatokon való részvétel

- Társas kapcsolatainak bővülése

- $\quad$ Folyamatos önfenntartó életmód kialakítása

- $\quad$ Folyamatos munkaviszony fenntartása

- $\quad$ A motiváció folyamatos fenntartása 
A fent megfogalmazott célok elérésében M. segítséget igényel egyéni szociális munka keretében az erőforrásait felkutató, erôsítő és folyamatosan támogató, az önálló életvitelre sarkalló segítségnyújtásban.

\section{A közös munka}

A program egy éves ideje alatt M. megtartotta az albérletet. A cél ez volt, és ez teljesült. Valós veszélyként értékeltem, hogy időközben nagy mértékben megemelkedett az albérlet díja. Úgy gondolom, hogy tudatos pénzügyi tervezéssel sikerült bebizonyítani, hogy lehet ezen változtatni. M. beosztja a jövedelmét, rendszeresen dolgozik, az albérletet meg akarja tartani. M. tisztában van vele, hogy ez csak erős kontroll mellett sikerülhet. Nagyon sokat segít nekem, mint segítő szakembernek, hogy egy motivált emberrel sikerül dolgoznom.

M. betegsége, illetve annak következménye kissé beárnyékolja valódi jellemét. Kicsit nehezen nyílik meg, s úgy vélem, hogy hiányoznak neki az emberi kapcsolatok. M. bekapcsolódott egy egyházi közösségbe. Úgy látom, hogy ebben találta meg önmagát. Édesanyjával és testvérével való kapcsolatát is elfogadhatónak tartja.

M.-mel való közös munkánkról csak pozitívan tudok írni. A csoportfoglalkozásokon mindig az előre megbeszéltek szerint, rendszeresen megjelent. Amennyire tőle tellett, aktívan próbált részt venni. Bár az mindig látszott, hogy nem szeret a középpontban lenni. Rendszeresen tartom vele a kapcsolatot, meglátogatom az albérletében. A lakás tiszta, rendezett. Találkozásainkkor megbeszéljük az elmúlt hetek történéseit. M. a főbérlöjével a kezdetektől fogva jó viszonyt alakított ki. A lakhatás megtartásában jól teljesített, a lakhatás kiadásait időben rendezte, nem volt elmaradása. A program ideje alatt sikerült minimális tartalékot képeznie, amelynek egy részét a bérlemény kifestésére fordította.

\section{Összegzés}

A program véget ért és M.-nek sikerült megtartani a lakhatását. Munkaviszonyát ismételten meghosszabbították, ez szintén örömre ad okot. M. jól érzi magát a munkahelyén, és úgy érzi, hogy öt is elfogadták. Heti szinten találkozunk, hol az irodában, hol az albérletben. Már többször átbeszéltük a további lehetőségeket. Nyíregyháza Város Önkormányzata helyi rendeletben szabályozza a hajléktalanoknak is adható lakbértámogatási hozzájárulást. A támogatás segíti a hajléktalan emberek lakhatásba jutását anyagi eszközökkel és segítő munkával. M. beadja a kérelmet, és bízom benne, hogy megkapja a támogatást. A megítélt támogatás egy évig folyósítható, ami az albérleti díj 60\%-a.

Véleményem szerint szükség van a hajléktalanoknak esélyt jelentő lakhatási programokra. Kihívás az, hogy esetmunkával kihozhatjuk az ügyfelekből a maximumot. Fontos a kliensnek, és nekünk is segítő szakembereknek a sikerélmény. Nekem abszolút pozitív, hogy M.-et végigkísérhettem ezen az úton. Bízom benne, hogy még sok hasonló élményben lesz részem. 